\title{
Blade Shape Analysis on The Performance of The Pelton Turbine Prototype
}

\author{
Ahmad Yani $^{1, a^{*}}$, Irianto $^{2, \mathrm{~b}}$, Joko Triyatno ${ }^{3, \mathrm{c}}$, Fitria $^{4, \mathrm{~d}}{ }_{\text {,Saripah Sobah }}{ }^{5, \mathrm{e}}$ \\ ${ }^{1,2,3}$ Department of Mechanical Engineering, Sekolah Tinggi Teknologi Industri Bontang \\ Jl. Brigjend Katamso No. 40, Bontang- Indonesia 75311 \\ ${ }^{4,5}$ Department of Chemical Engineering, Sekolah Tinggi Teknologi Industri Bontang \\ Jl. Brigjend Katamso No. 40, Bontang - Indonesia 75311 \\ *a yanibima@gmail.com \\ biriantosmart@gmail.com \\ jokotriyatno@yahoo.com \\ dtekimfitri@gmail.com \\ esobahbtg@gmail.com
}

\begin{abstract}
Water turbine is one of the driving machines where the working fluid is water that is used directly to spin the turbine runner. This research was conducted using a Pelton type water turbine installation with variations in the shape of the turbine blade. The research method used is an experimental activity with a laboratory is scaled up for experimental purpose. The experimental design of this research is used as well for laboratory experimental activity for students in mechanical engineering department in the institution. The results show the influence of turbine blade shape on the performance of the Pelton water turbine prototype, therefore, it can be concluded that the maximum tangential velocity is $12.141 \mathrm{rad} / \mathrm{s}$, the hydraulic power measured is 2.64 Watts, the kinetic power is 3.886 Watts, the maximum turbine power is 99.141 Watts, the maximum electric generator power is 99.141 Watts, the maximum turbine efficiency is $25.512 \%$, and the maximum electric generator efficiency is $0.661 \%$.
\end{abstract}

\section{Keywords-Blade Shape, Performance, Pelton Turbine}

\section{Introduction}

A water turbine is one of the driving machines where the fluid works are the water that is used directly to spin the turbine wheels. In the turbine wheels, there is a blade and fluid work flowing through the space between the blade [1]. A Pelton turbine is an impulse turbine, which is a turbine-driven by an energy kinetic water. High-accuracy water sprays about the blade and after moving the water runner out at low speeds, meaning that some of their energy is not absorbed by the runner. Water pressure in and out of the blade is atmospheric pressure [2]. The laboratory is a place to train students in terms of practicing skills, demonstrations, experiments, research, and the development of science. The existence of the laboratory as a place of the practicum is necessary to improve student skills. The implementation of practical activities is conducted in the provision of learning experience to the students so that students can interact with lesson materials and direct observation of symptoms that occur in the water turbine test equipment. Practice activities in the laboratory can improve student skills when used efficiently because with the experiments students can understand the courses that require a concrete passion by doing real activities through experiment [3]. Similar with a research that was conducted previously in 2017 [4], [5], where a variation of the shape of the blade against torque and power of water turbine were applied. Moreover, a variation of turbine nozzle diameter with the turbine round braking method were applied as well. This advanced research is conducted by modifying the water turbine designed by varying the blade shape of the turbine to investigate the performance of the prototype Pelton water turbine. The shape of the turbine blade greatly determines the rotation of the turbine therefore, it can improve the turbine performance. For that reason, this research is aimed to determine the appropriate shape of the blade to produce the maximum turbine performance.

\section{Research Methodology}

The study was conducted using an experimental method with a laboratory-scale experimental design using Pelton water turbine equipment as shown in Figure 1. the shape of the turbine blade is varied to investigate the most optimum blade shape for maximum turbine's performance.

\section{A. Research Variable}

There are three types of variables used in this study; free variables, bound variables and controlled variables. 
a. Free Variable

The free variables on this study consist of:

1. Water discharge: $0.0005 \mathrm{~m}^{3} / \mathrm{s}$

2. Total of 18-piece turbine

3. The shape of the spoon include: a flat blade, a curved spoon, a half-cylinder blade, a teaspoon of rice, and a blade bowl.

b. Controlled Variable

1. A blade angle is conditioned constant at $90^{\circ}$ position.

2. Turbine nozzle size is $1 / 2$ inches

b. Bound Variables

The variables used in this research are angular velocity, hydroelectric power of water, kinetic power of water, turbine power, electricity generator power, turbine efficiency and power generator efficiency.

\section{B. Research Procedure}

The testing procedure for the research data collection is as follows:

1. Create a table to record the test results.

2. Preparing and installing all research installations and measuring instruments used.

3. Install the nozzle $1 / 2$ Inch size as specified.

4. Install a flat turbine blade shape first for data retrieval.

5. Check all the turbine components studied to ensure readiness before starting to turn on the water pump and make sure all the measuring instrument conditions are in good condition.

6. Press the switch/button to turn on the water pump.

7. Measure the discharge of water flow using the flowmeter measuring instrument, and record the result of the measurement.

8. Measure the rotation of the turbine shaft and round the generator shaft with the tachometer gauge, then record the turbine rotation value on the tachometer gauge.

9. Measures the output voltage and output current on the turbine generator that is loaded with the lamp and records the value of the power voltage and electric current on the Multi tester gauge.

10. Repeat the data retrieval at step 4 by attaching the shape of the curved spoon, rice scoop, half-cylinder, and the spoon-bowl shape until the data retrieval step number nine.

11. Processing and analyzing the research data obtained to determine the performance value of the water turbine studied.

12. Draw conclusions from the results of the research.

\section{Installation of The Research Tools}

The dimension of the research equipment is $110 \mathrm{~cm}$ of length, width of $60 \mathrm{~cm}$, and height of $40 \mathrm{~cm}$ made of iron plate elbow. The water container size of $60 \mathrm{~cm} \times 60$ $\mathrm{cm}$ is made of a sheet of the iron plate with a thickness of $0.3 \mathrm{~cm}$. While the runner size of the turbine is 21.5 $\mathrm{cm}$ in diameter. While the turbine shaft size is $2.54 \mathrm{~cm}$ diameter with a length of $80 \mathrm{~cm}$. In this research testing tool, the used water turbine is a type of horizontal shaft Pelton whose research installation design is shown in Figure 1.

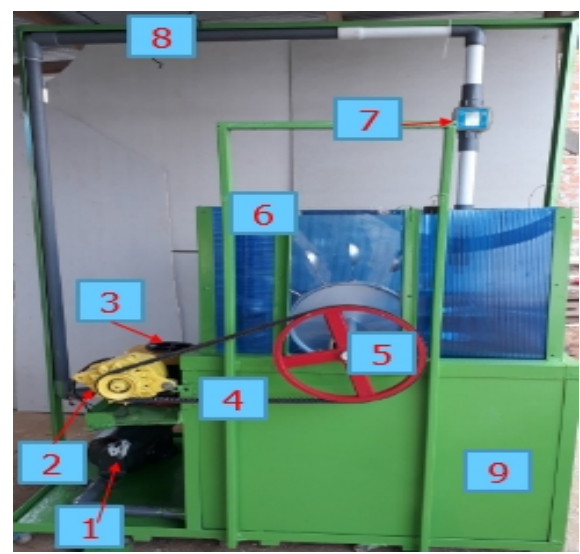

Figure 1. Design Installation setup of the Proposed Research

Figure 1 description:

1. Water pump

2. Electricity generator

3. 12 Volt Battery

4. V-belt

5. Pulley

6. Turbine Installation Frame

7. Flow meter

8. 1 inch PVC pipe

9. Water Collection Tank

Pelton water turbine testing is to expect to obtain the maximum turbine performance [6]. The calculation process for obtaining turbine performance using equations (1) through equation (11) [2], [7].

\section{Cross-sectional area of the nozzle tip (A)}

To calculate the cross-sectional area of the nozzle tip, use equation (1).

$$
A=\frac{1}{4} \cdot \pi \cdot d^{2}
$$

Where:

$\mathrm{A}=$ Extent tip nozzle $\left(\mathrm{m}^{2}\right)$.

$\mathrm{d}=$ Inside diameter of the nozzle $(\mathrm{m})$

\section{Flow Capacity (Q)}

To calculate the flow capacity using equation (2). 


$$
Q=A \cdot V
$$

Where:

$$
\begin{aligned}
& \mathrm{Q}=\text { Discharge of water flow }\left(\mathrm{m}^{3} / \mathrm{s}\right) \\
& A=\text { Extent tip nozzle }\left(\mathrm{m}^{2}\right) \\
& \text { V = Flow velocity }(\mathrm{m} / \mathrm{s})
\end{aligned}
$$

\section{Flow Speed (V)}

To calculate the flow velocity using equation (3).

Where:

$$
V=\frac{Q}{A}
$$

$\mathrm{V}=$ Flow velocity $(\mathrm{m} / \mathrm{s})$.

$\mathrm{Q}=$ Discharge of water flow $\left(\mathrm{m}^{3} / \mathrm{s}\right)$.

$\mathrm{A}=$ Extent tip nozzle $\left(\mathrm{m}^{2}\right)$.

\section{Flowing Mass of Water $(\dot{m})$}

To calculate the mass of the flow using equation (4).

Where:

$$
\dot{m}=\rho \cdot Q
$$

$\dot{m}=$ Mass water flow rate $(\mathrm{kg} / \mathrm{s})$

$\rho=$ Density of water $\left(\mathrm{kg} / \mathrm{m}^{3}\right)$.

$Q=$ Discharge of water flow $\left(\mathrm{m}^{3} / \mathrm{s}\right)$.

\section{Angular Speed ( $\omega)$}

To get the angular velocity value use equation (5).

Where:

$$
\omega=\frac{2 \cdot \pi \cdot n}{6}
$$

$\omega=$ Angular Speed $(\mathrm{rad} / \mathrm{s})$

$\mathrm{n}=$ Turbine rotation $(\mathrm{rpm})$

\section{Calculation of Power}

a. Hydraulic Power

Hydraulic power is calculated using equation (6).

Where:

$$
P_{h}=\rho . g . Q . H
$$

$\mathrm{P}_{\mathrm{h}}=$ Hydraulic power (Watt)

$\rho=$ Density of water $996.74\left(\mathrm{~kg} / \mathrm{m}^{3}\right)$.

$\mathrm{g}=$ Earth's gravity force, $9.81\left(\mathrm{~m} / \mathrm{s}^{2}\right)$.

$\mathrm{Q}=$ Discharge of water flow $\left(\mathrm{m}^{3} / \mathrm{s}\right)$.

$\mathrm{H}=$ Turbine head (m).

\section{b. Kinetic power of water jets}

The kinetic power of water is calculated using equation (7).

$$
\mathrm{P}_{k}=\frac{1}{2} \cdot \rho \cdot A \cdot v^{3}
$$

Where:

$\mathrm{P}_{k}=$ Kinetic power of water (Watts).

$\rho=$ Density of water $996.74\left(\mathrm{~kg} / \mathrm{m}^{3}\right)$.

DOI : http://dx.doi.org/10.31963/intek.v7i1.2055
$A=$ Turbine nozzle cross-sectional area $\left(\mathrm{m}^{2}\right)$.

$v=$ Flow velocity $(\mathrm{m} / \mathrm{s})$.

c. Turbine Power

To calculate the turbine power use equation (8).

$$
\mathrm{P}_{\mathrm{t}}=\rho . \text { A. } \omega .(\Omega-\mathrm{v}) \cdot(1+\operatorname{Cos} \theta) \cdot \mathrm{V}
$$

Where:

$\mathrm{P}_{\mathrm{t}}=$ Water turbine power (Watt).

$\rho=$ Density of water $996.74\left(\mathrm{~kg} / \mathrm{m}^{3}\right)$.

$\mathrm{A}=$ Turbine nozzle cross-sectional area $\left(\mathrm{m}^{2}\right)$.

$\omega=$ Angular velocity $(\mathrm{rad} / \mathrm{s})$.

$\mathrm{v}=$ Flow velocity $(\mathrm{m} / \mathrm{s})$.

$\operatorname{Cos} \theta=$ Water jet angle/ Nozzle position $\left(^{\circ}\right)$

d. Electric Power (Generator Power)

To calculate electric power using equation (9).

$$
P_{g}=\text { V. I. Cos } \phi
$$

Where:

$\mathrm{P}_{\mathrm{g}}=$ Electric power (generator power) (Watt)

$\mathrm{V}=$ Electric generator output voltage (Volt)

$\mathrm{I}=$ Electric generator output current (Ampere)

$\operatorname{Cos} \phi=$ Power factor (degree)

\section{Calculation of Efficiency ( $\eta$ )}

a. Turbine Blade Efficiency

To calculate the efficiency of a turbine use equation (10).

Where:

$$
\eta_{t}=\frac{P_{t}}{P_{k}} x 100 \%
$$

$\eta_{\mathrm{t}}=$ Water turbine efficiency (\%).

$\mathrm{P}_{\mathrm{t}}=$ Turbine power (Watt).

$\mathrm{P}_{\mathrm{k}}=$ Kinetic power of water (Watts).

\section{b. Turbine Generator Efficiency}

To calculate the efficiency of a generator using equation (11).

$$
\eta_{g}=\frac{P_{g}}{P_{h}} x 100 \%
$$

Where:

$\eta_{g}=$ Turbine generator system efficiency (\%).

$\mathrm{P}_{\mathrm{g}}=$ Turbine generator power (Watt).

$\mathrm{P}_{\mathrm{h}}=$ Water hydraulic power (Watt). 


\section{Results and Discussion}

These tests were conducted to obtain turbine round data, generator rounds, power output naps, electric generator output currents, turbine heads, and flow discharge. Data analysis techniques using descriptive techniques based on the results of the research conducted from the field test data. The next step is to carry out data processing or mathematical calculations as shown in equation (1) to (11) with objectives for obtaining the value of hydraulic power, kinetic power, turbine power, power generators, turbine efficiency, and generator efficiency. The relationship between the turbine-shaped blade-performance of the Pelton water turbine is shown in Fig. 2 to 8.

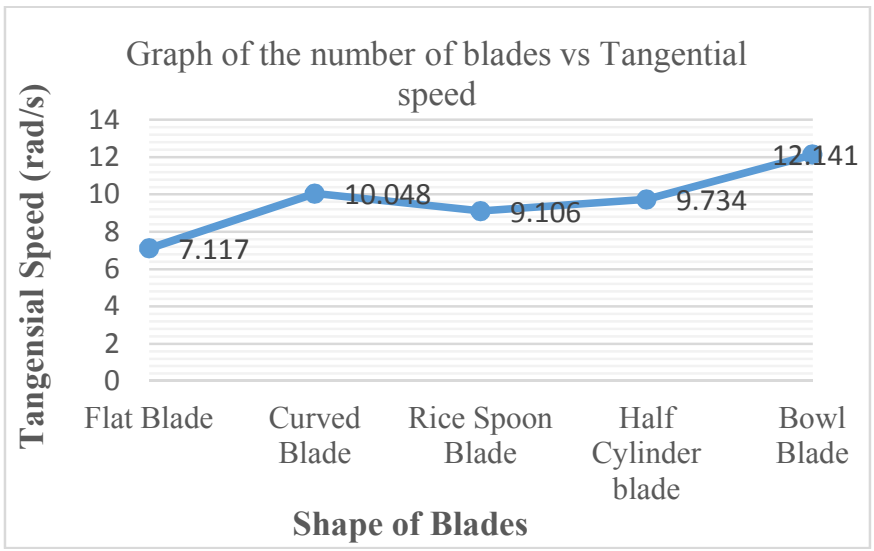

Figure 2. Graph of the number of blades vs Tangential speed

As can be seen in Figure 2, the blade shape affects tangential velocity. The maximum tangential velocity occurs in the shape of a bowl blade with a value of $12.141 \mathrm{rad} / \mathrm{s}$, this phenomenon may be caused by the shape of the bowl blade that can hold water so that the water exerts a thrust force on the turbine blade which causes the tangential speed to increase. The more precise the shape of the turbine blade, the turbine rotation will increase and the turbine rotation will affect the tangential force generated and the tangential force will affect the tangential velocity. The lowest tangential velocity occurs in the form of a flat blade with a value of $7.117 \mathrm{rad} / \mathrm{s}$. this is caused by the shape of a flat blade that cannot hold water so that the water directly exits the blade and causes the small tangential force produced and causes a small tangential velocity.

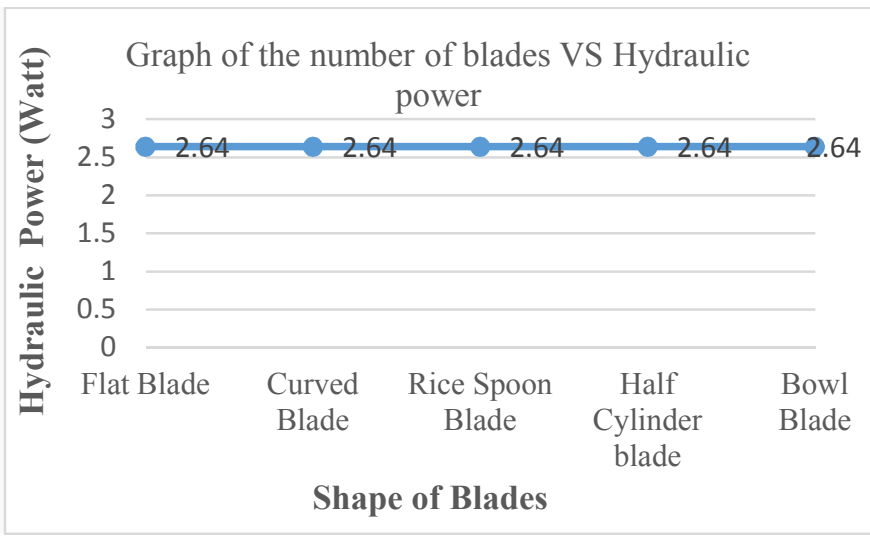

Figure 3. Graph of the number of blades water hydraulic power

Base on the data field testing which is then performed in mathematical data processing using equation (6), it can be concluded that the shape of the blade does not affect hydraulic power of the water, this occur due to the use of the same flow rate and turbine head. Therefore, there is no difference in the hydraulic power value of water. The value of hydraulic power in this study is 2.64 Watt.

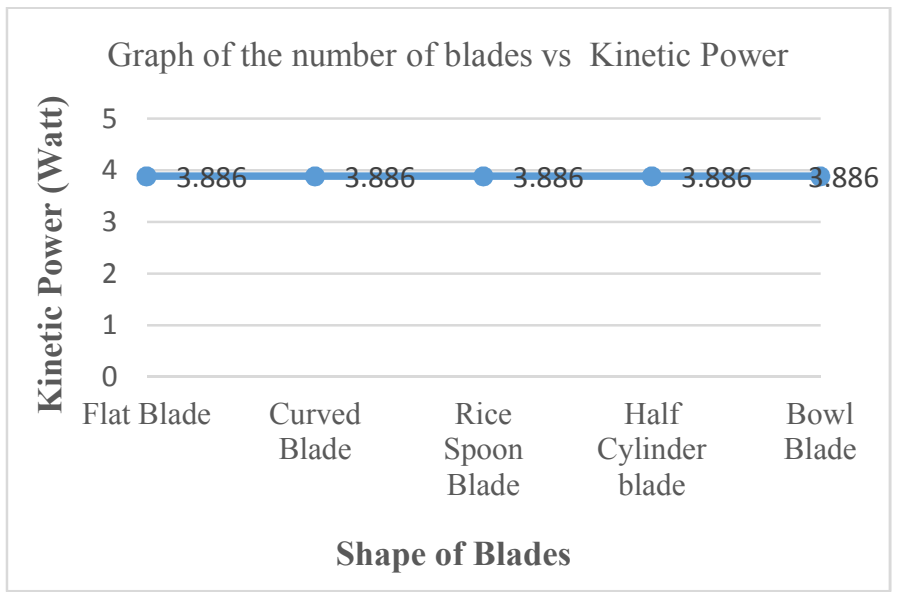

Figure 4. Graft The number of Blades vs Water Kinetic Power

Based on field testing data which is then performed mathematical data processing using equation (7), it can be concluded that the shape of the blade does not affect the hydraulic power of the water, because in this study using a turbine nozzle size which in turn the speed of water flowing out through the nozzle at each turbo blade shape test is the same. From the results of research data processing, the kinetic power value of water in the study is measured at 3,886 Watt. 


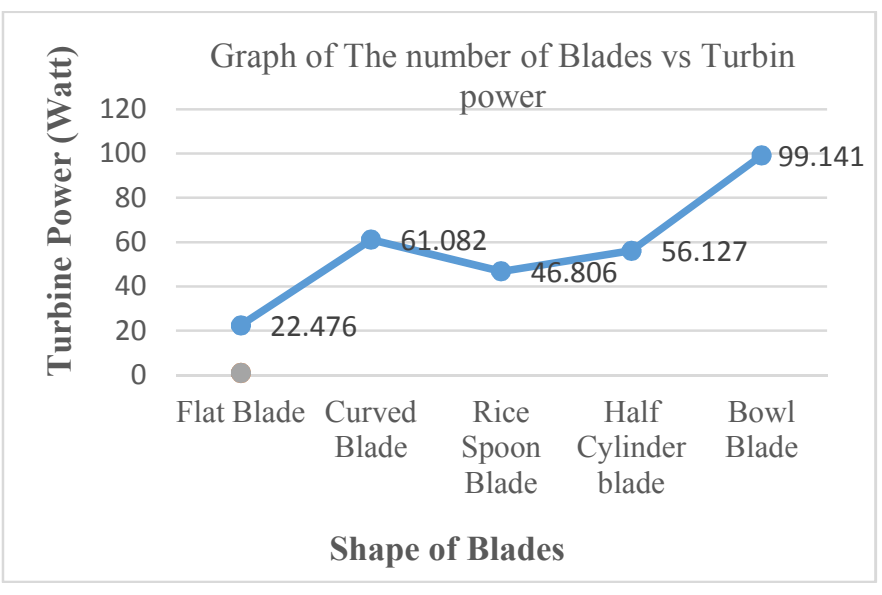

Figure 5. Graph of the number of blades vs Turbine Power

Based on Figure 5 it can be concluded that the shape of the blade influences the power of the turbine. Maximum turbine power occurs in the shape of a bowl blade with a value of 99.141 Watt, this occurs due to the water that hits the turbine blade is blocked by the shape of the bowl blade so that the tangential force produced increases and the tangential force affects the tangential velocity and the tangential velocity affects the turbine power produced. The lowest turbine power occurs in the form of flat blade with a value of 22.476 Watt, this occurs because the water that hits the flat blade immediately spreads out the turbine blade so that the tangential speed produced is not as great as the shape of the curved blade, rice spoon blade, half-cylinder blade and bowl shape.

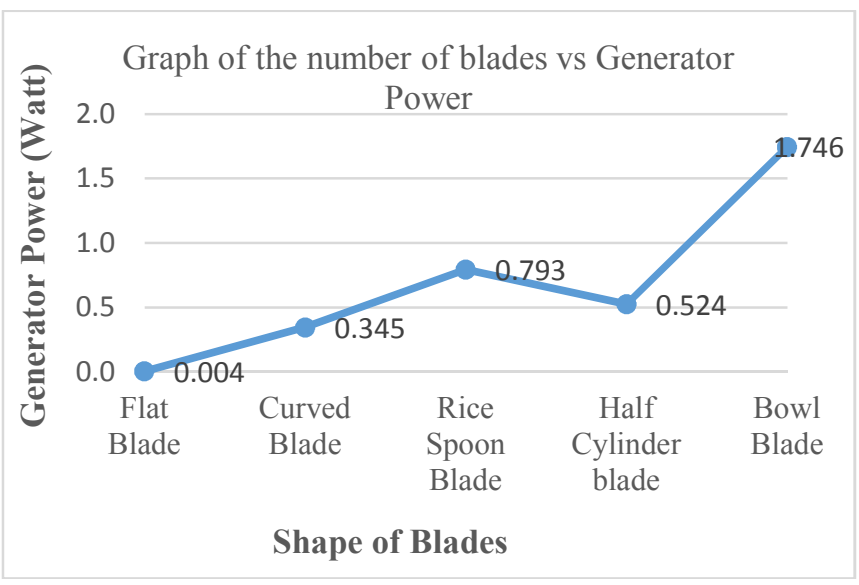

Figure 6. Graph of The number of Blades VS Electric Generator Power

Figure 6 shows that the shape of the blade affects the power of the electric generator (electric power).
Maximum electric generator power occurs in the form of a bowl blade with a value of 99.141 Watt, this phenomenon may be caused by the shape of the bowl blade which can produce a higher tangential velocity, thereby causing the turbine runner rotation to increase and cause the electric generator rotation to increase so as to produce a higher electric current, because electric generator power affects the value of the electric voltage and the value of the electric current generated. The lowest power generator power is 22.476 Watt. this is caused by the shape of the flat blade that cannot hold water so that the resulting tangential speed is small and causes the turbine runner and electric generator rotation to decrease.

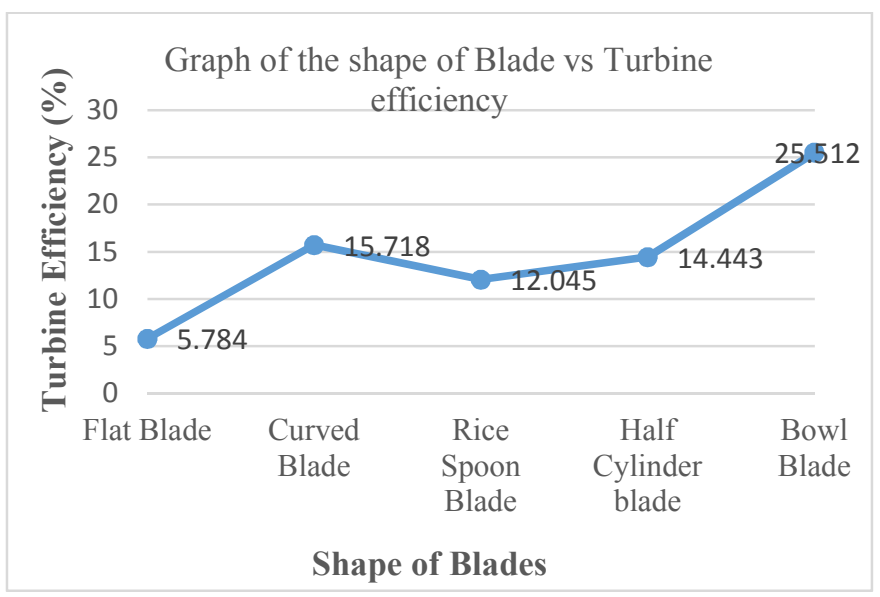

Figure 7. Graph of the shape of Blade vs Turbine efficiency

As shown in Figure 7, it can be seen that the blade shape influences the efficiency of the turbine. Maximum turbine efficiency occurs in the shape of a bowl blade with a value of $25.512 \%$, this phenomenon may be caused by the shape of the bowl blade that can hold water so that the water exerts thrust on the bowl blade which causes tangential velocity to increase and tangential speed affects the turbine power, because turbine efficiency affect the turbine power, the higher the turbine power value, the turbine efficiency will also increase. The lowest turbine efficiency occurs in the form of a flat blade with an efficiency value of 5.784\%. this is because water that strikes the flat blade immediately spreads leaving the turbine blade so that the tangential velocity and power of the turbine produced is not as great as the shape of the curved blade, rice spoon blade, half-cylinder blade and the shape of the bowl blade. 


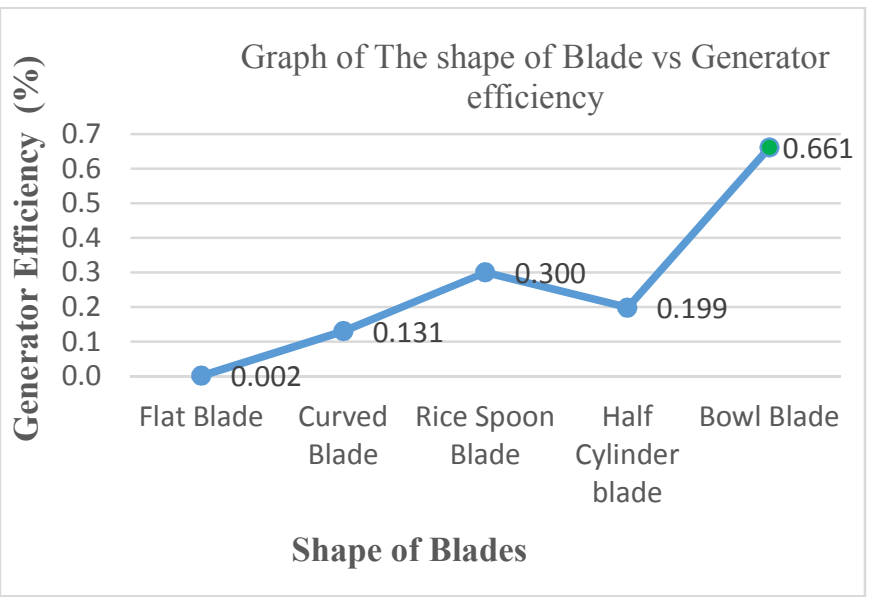

Figure 8. Graph of the shape of Blade vs Electric Generator Efficiency

Based on Figure 8, the blade shape influences the efficiency of the electricity generator. The maximum efficiency of the electric generator occurs in the form of a bowl blade, based on the results of data processing using equation 11, it can be concluded that the value of the maximum efficiency of the electric generator is $0.661 \%$, this phenomenon may be caused by the shape of the bowl blade which can produce a turbine runner rotation speed and an electric generator rotation is higher so increase the value of the power generator produced and the value of the power generator is directly proportional to the value of the efficiency of the electricity generator. The efficiency of the lowest electric generator is $0.002 \%$, this is due to the fact that the shape of the flat blade results in a relatively small tangential speed resulting in the turbine runner rotation and the rotation of the electric generator decreasing, ultimately affecting the efficiency of the electric generator.

\section{Conclusion}

The results showed the influence of turbine blade shape on the performance of the Pelton water turbine prototype, therefore, it can be concluded that the maximum turbine performance occurs in the shape of a bowl blade where the maximum tangential velocity is $12.141 \mathrm{rad} / \mathrm{s}$, the hydraulic power value is $2.64 \mathrm{Watt}$, the kinetic power value is 3.886 Watts, maximum turbine power 99.141 Watts, maximum electric generator power 99.141 Watts, maximum turbine efficiency $25.512 \%$, and maximum electric generator efficiency of $0.661 \%$.

\section{References}

[1] Arismunandar., W. "Penggerak Mula Turbin"(Turbine Prime Mover) Edisi III, ITB, Bandung. 2004.

[2] Hamidi, Supandi, and Rohermanto, A, "Rancang Bangun Model Turbin Pelton Mini Sebagai Media Simulasi/Praktikum Mata Kuliah Konversi Energi dan Mekanika Fluida"(Construction of the Pelton turbine Model Mini For Media Simulation / Practical Course Fluid Mechanics and Energy Conversion) Scientific Journal Semesta Teknika, Department of Mechanical Engineering Polytechnic Pontianak. Vol 9, No. 1. pp 1624, 2006.

[3] Prasetyo, G. and Dharma, U. S, "Pengaruh Perubahan Laju Aliran terhadap Tekanan dan Jenis Aliran yang Terjadi pada Alat Uji Praktikum Mekanika Fluida", (Influence of Flow Rate Changes Against Pressure and Flow Type Happens At Practice Test Equipment Fluid Mechanics). Turbo Journal. Study Program Faculty of Engineering, University of Muhammadiyah Metro. Lampung. Vol 1, No. 2. pp 106-115, December 2012.

[4] Yani. A, "Rancang Bangun Alat Praktikum Turbin Air dengan Pengujian Bentuk Sudu terhadap Torsi dan Daya Turbin yang Dihasilkan", (The design of practical tools to test water turbine blade shape of the torque and power produced by the turbine). Turbo Journal. Department of Mechanical Engineering, Faculty of Engineering, University of Muhammadiyah Metro. Lampung.Vol 6, No. 1. pp 22-30, June 2017.

[5] Rosmiati and Yani. A, "Pengaruh Variasi Diameter Nosel Terhadap Torsi dan Daya Turbin Air”, (The Influence of the nozzle diameter variation of the torque and power of water turbines). Turbo Journal. Department of Mechanical Engineering, Faculty of Engineering, University of Muhammadiyah Metro - Lampung. Vol 6, No. 1. pp 14-21, June 2007.

[6] Yani. A, Mihdar and Erianto. R. "Pengaruh Variasi Bentuk Sudu terhadap Kinerja Turbin Air Kinetic", (The effect of variations on the Performance of Water turbine blade kinetic" (For Power Plant Rural). Turbo Journal. Department of Mechanical Engineering, Faculty of Engineering, University of Muhammadiyah Metro. Lampung. Vol 5, No. 1. pp 8-13, June 2016.

[7] Yani. A, Susanto. B and Rosmiati. "Analisis Jumlah Sudu terhadap Kinerja Turbin Pelton pada Alat Praktikum Turbin Air", (Analysis of Number of Blades on Pelton Turbine Performance in Water Turbine Practicum Tools), Turbo Journal. Department of Mechanical Engineering, Faculty of Engineering, University of Muhammadiyah Metro. Lampung..Vol 7, No. 2. pp 185-192, December 2018. 